\title{
Neuronal NT-3 Is not Required For Synaptic Transmission or Long-Term Potentiation in Area CA1 of the Adult Rat Hippocampus
}

Long Ma, ${ }^{1,3}$ Gerald Reis, ${ }^{2,3}$ Luis F. Parada ${ }^{1}$ and Erin M. Schuman ${ }^{2,4}$

${ }^{1}$ University of Texas, Southwestern Medical Center

Center for Developmental Biology

Dallas, Texas 75235-9133 USA

${ }^{2}$ Caltech/Howard Hughes Medical Institute (HHMI)

Division of Biology 216-76

Pasadena, California 91125 USA

\section{Abstract}

Neurotrophic factors, including BDNF and NT-3, have been implicated in the regulation of synaptic transmission and plasticity. Previous attempts to analyze synaptic transmission and plasticity in mice lacking the NT-3 gene have been hampered by the early death of the NT-3 homozygous knockout animals. We have bypassed this problem by examining synaptic transmission in mice in which the NT-3 gene is deleted in neurons later in development, by crossing animals expressing the CRE recombinase driven by the synapsin I promoter to animals in which the NT-3 gene is floxed. We conducted blind field potential recordings at the Schaffer collateral-CA1 synapse in hippocampal slices from homozygous knockout and wild-type mice. We examined the following indices of synaptic transmission: (1) input-output relationship; (2) paired-pulse facilitation; (3) post-tetanic potentiation; and (4) long-term potentiation: induced by two different protocols: (a) two trains of $100-\mathrm{Hz}$ stimulation and (b) theta burst stimulation. We found no difference between the knockout and wild-type mice in any of the above measurements. These results suggest that neuronal NT-3 does not play an essential role in normal synaptic transmission and some forms of plasticity in the mouse hippocampus.

\footnotetext{
${ }^{3}$ These two authors contributed equally.

${ }^{4}$ Corresponding author.
}

\section{Introduction}

Neurotrophic factors, including BDNF and NT3 , have been implicated in the regulation of synaptic transmission and plasticity (for a recent review, see Schuman 1999). For example, BDNF and NT-3 have been found to enhance synaptic transmission at the neuromuscular junction (Lohof et al. 1993) and in area CA1 of the hippocampus (Kang and Schuman 1995). In addition, the induction of longterm potentiation (LTP) leads to increases in both BDNF and NT-3 mRNA levels in area CA1 of the hippocampus (Patterson et al. 1992). Mice with a targeted disruption of the BDNF gene show diminished LTP in the hippocampus (Korte et al. 1995, 1996; Patterson 1996 ). In addition, application of TrkB-IgG fusion proteins can interfere with both early (Figurov et al. 1996; Kang et al. 1997) and late (Kang et al. 1997) LTP in the hippocampus and visual cortex (Akaneya et al. 1997). Unfortunately, similar studies using genetic or pharmacological disruptions of NT-3 function have not been reported owing to mice mortality and lack of reagent availability, respectively.

Although most of the homozygous NT-3 knockout mice die within a few days of birth (Ernfors et al. 1994), the heterozygous animals live throughout adulthood, permitting an analysis of synaptic transmission. At the lateral perforant pathgranule cell synapse in the dentate gyrus, slices from heterozygous (+/-) knockout animals exhibited normal LTP, but diminished paired-pulse facilitation and post-tetanic potentiation (Kokaia et al. 1998). As of yet, synaptic transmission and plasticity in area CA1 of the hippocampus has not been examined in these mice.

NT-3 is expressed in both neurons and glia

LEARNING \& MEMORY 6:267-275 @ 1999 by Cold Spring Harbor Laboratory Press ISSN1072-0502/99 \$5.00

$$
\begin{array}{lllllllllllllll}
L & E & A & R & N & I & N & G & \underset{\mathbf{2 6 7}}{\boldsymbol{Z}} & M & E & M & O & R & Y
\end{array}
$$


(Tessarollo et al. 1993). Studies using pharmacological manipulations to examine the contribution of a particular molecule to plasticity are often compromised by an inability to address the source or site of action of the molecule of interest. A similar concern exists for genetic deletion experiments in which a gene is deleted in all cell types. By engineering a transgenic mouse in which the NT-3 gene is selectively deleted in neurons, the present study allowed us to address the contribution of neuronal NT-3 to both synaptic transmission and plasticity in the hippocampus.

\section{Materials and Methods}

\author{
PCR FOR NT-3-LOXP DELETION
}

PCR primer P1 5' -TTACCTGCTCATGAAGAAGCCTTGTTGAGC-3' and primer P3 5'-GCATGGTTTCTGGCAGTCATAGATGCTTCC- $3^{\prime}$ were used to detect the deletion of NT-3-loxp allele. Before deletion, these two primers were $5 \mathrm{~kb}$ apart and would not generate a visible band with the following cycling conditions. After deletion, these two primers would be only 200 bp apart and would give a 200-bp PCR band in $1.5 \%$ agarose gel. PCR cycling conditions were $94^{\circ} \mathrm{C}, 30 \mathrm{sec} ; 65^{\circ} \mathrm{C}, 30 \mathrm{sec}$; $72^{\circ} \mathrm{C}, 30 \mathrm{sec}$ for 32 cycles.

GENERATION OF NT-3 CONDITIONAL KNOCKOUT MICE

Targeting vector construction, embryonic stem (ES) cell experiments, and chimeric mice will be described in detail elsewhere (L. Ma, J. Marth, and L.F. Parada, in prep.). After germ-line transmission of the NT-3-loxp allele was obtained, these mice were mated with different Cre-expressing mouse lines. In the present case, a transgenic mouse line expressing Cre recombinase under the control of the Synapsin I promoter (SynI-Cre) provided by Dr. J. Marth (University of California, San Diego), was used to generate a conditional knockout of NT-3 specifically in the central nervous system. lacZ reporter mice (Tsien et al. 1996) were mated with SynI-Cre transgenic mice to generate lacZ-expressing mice recapitulating Cre expression. We have estimated the activation time of the synapsin I promoter in our mice by examining its ability to drive expression of lacZ. At embryonic day 11.5 (E11.5) a very weak expression of lacZ can be observed, but robust expression of lacZ starts at E12.5. Analysis of the expression pattern of $l a c Z$ indicates strongest expression is in differentiated neurons.

\section{SOUTHERN BLOT HYBRIDIZATION}

Mouse brain genomic DNA (10-30 $\mu \mathrm{g})$ from 5-week-old animals was digested with EcoRI and resolved on $0.8 \%$ agarose gel, blotted onto nylon membranes (Amersham), and hybridization was performed using either $2.2-\mathrm{kb} 5^{\prime}$ or $1.4-\mathrm{kb} 3^{\prime} \mathrm{ex}-$ ternal probes as detailed in Figure 1a. The filters were then washed once with $1 \times$ SSC, $0.1 \%$ SDS at $65^{\circ} \mathrm{C}$ for $1 \mathrm{hr}$, then once with $0.5 \times \mathrm{SSC}, 0.1 \%$ SDS at $65^{\circ} \mathrm{C}$ for $30 \mathrm{~min}$ (Sambrook et al. 1989).

\section{NORTHERN BLOT HYBRIDIZATION}

Mouse brain total RNAs from 5-week-old animals were prepared using Trizol (GIBCO-BRL) and separated on $2.2 \mathrm{~m}$ formaldehyde and 1\% agarose gels. Northern blot was performed on Nylon membranes. An NT-3 cDNA fragment $(0.8 \mathrm{~kb})$ was used as probe for hybridization. Washing conditions were as described for Southern blot hybridization (above). After exposure for NT-3 mRNA signals, the membrane was stripped and rehybridized with GAPDH probe (Sambrook et al. 1989).

\section{PHOSPHORIMAGER QUANTIFICATION}

Either Southern or Northern membranes were exposed to PhosphorImager screens and the signal intensity of each band was measured as described by the manufacturer (Bio-Rad). Percentage of NT3-loxp (cko-) deletion or NT-3 mRNA reduction was calculated based on the relative signal intensities.

\section{X-GAL STAINING OF BRAIN SECTIONS}

PO mouse pups were perfused with $4 \%$ paraformaldehyde. Whole brains were embedded in chicken albumin and sectioned as $100-\mathrm{mm}$ coronal sections with a virbratome. The brain sections were stained in $1 \times \mathrm{PBS}, 2 \mathrm{~mm} \mathrm{MgCl}_{2}, 50 \mathrm{~mm}$ potassium ferri/ferrocyanide, $1 \mathrm{mg} / \mathrm{ml} \mathrm{X-gal} \mathrm{at} 25^{\circ} \mathrm{C}$ for $48 \mathrm{hr}$.

\section{ELECTROPHYSIOLOGICAL RECORDING AND ANALYSIS}

Hippocampal slices $(400 \mu \mathrm{m})$ were prepared from young adult (31- to 45-day-old) male mice us-

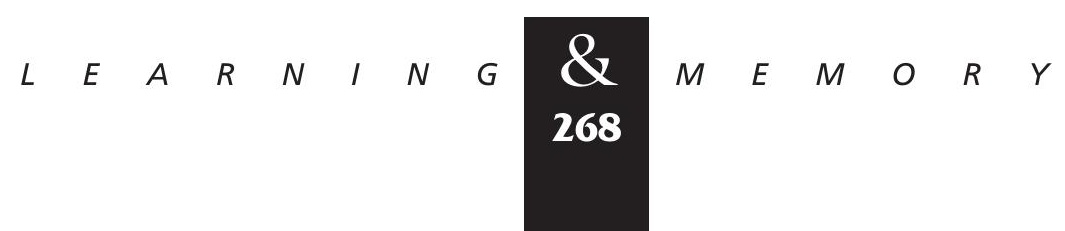


ing a vibratome. Immediately after dissection, individual slices were placed in a well of a 24 -well plate containing oxygenated artificial cerebral spinal fluid (ACSF). The plate was stored in an enclosed chamber saturated with $95 \% \mathrm{O}_{2}$ and $5 \% \mathrm{CO}_{2}$. The ACSF was then replaced by $250 \mu$ of oxygenated slice medium consisting of ACSF (119 mm NaCl, 2.5 $\mathrm{mm} \mathrm{KCl}, 1.3 \mathrm{~mm} \mathrm{MgSO}_{4}, 2.5 \mathrm{~mm} \mathrm{CaCl}_{2}, 2.0 \mathrm{~mm}$ $\mathrm{NaH}_{2} \mathrm{PO}_{4}, 26.2 \mathrm{~mm} \mathrm{NaHCO}, 20.0 \mathrm{~mm}$ glucose) supplemented with B-27 (GIBCO). Slices were incubated for at least $2 \mathrm{hr}$ before recording. For electrophysiological recordings, slices were submerged in a stream of ACSF maintained at $29 \pm 1^{\circ} \mathrm{C}$ and gassed with $95 \% \mathrm{O}_{2}$ and $5 \% \mathrm{CO}_{2}$. Field excitatory postsynaptic potentials/currents (EPSPs) measured in stratum radiatum were evoked by stimulation of the Schaffer collateral-commissural afferents at a rate of $0.033 \mathrm{~Hz}$ using bipolar stimulating electrodes. To be included for further analysis baseline field EPSPs of slope -0.2 to $-0.3 \mathrm{mV} /$ msec had to be elicited with stimulation currents $\leq 50 \mu \mathrm{A}$ and have fiber volley amplitudes $\leq 0.15$ $\mathrm{mV}$. Extracellular recording electrodes were filled with $3 \mathrm{M} \mathrm{NaCl}$. The initial slope of the EPSP was measured for all experiments. Input-output (I/O) relations were monitored by measuring the EPSP slope in response to increasing stimulation currents. Paired-pulse facilitation was measured at four different intervals: 10, 25, 50, and $100 \mathrm{msec}$. Tetanic stimulation was delivered at the test intensity in 1-sec trains at $100 \mathrm{~Hz}$, with two trains delivered $15 \mathrm{sec}$ apart. Theta-burst stimulation (TBS) consisted of one episode of the following: 10 bursts of stimuli, each of four pulses at $100 \mathrm{~Hz}$; interburst interval, $200 \mathrm{msec}$. Paired or unpaired $t$-tests were used to calculate the statistical significance of within group or between group comparisons, respectively. A one-way analysis of variance was used to calculate the statistical significance of potential differences between the I/O curves. $P$ values greater than 0.05 were considered not significant (N.S.). All of the electrophysiology and analysis were conducted with the experimenter blind to the genotype of the animal.

\section{Results}

GENERATION OF NT-3 CONDITIONAL KNOCKOUT MICE

The NT-3 conditional knockout mice were generated as illustrated in Figure 1 and will be de- a
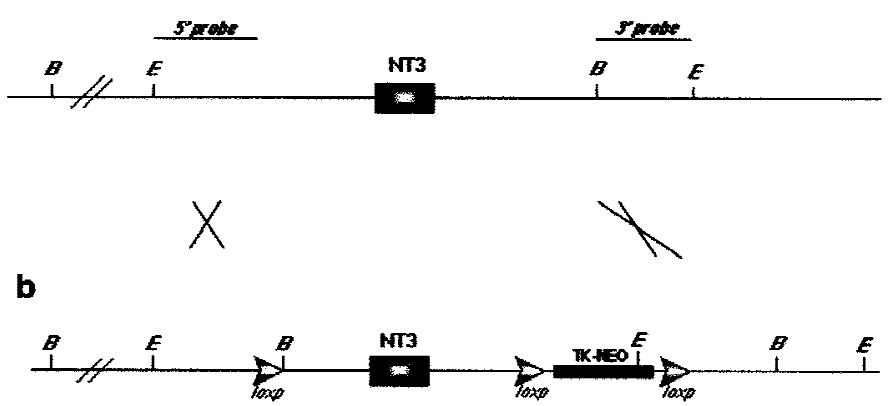

C

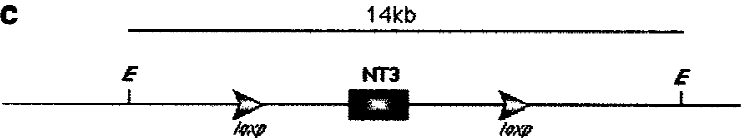

cko+

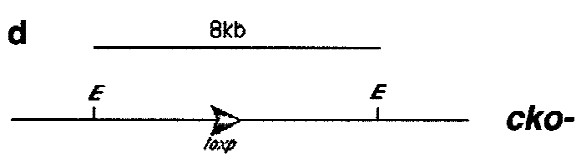

Figure 1: Strategy for generating NT-3 conditional knockout mice. (a) Genomic structure of mouse NT-3 gene. (b) Homologous recombinant allele. Targeting vector was transfected into CJ7 ES cells and the details of selection were as described previously (Tessarollo et al. 1994). Homologous recombination was screened with Southern blot using both $5^{\prime}$ and $3^{\prime}$ probes. (c) Generation of $c k o^{+}$allele. Recombinant ES clones were transfected with a CMV-Cre-expressing plasmid to delete the TK-neo selection cassette (Kuhn et al. 1995; Ramirez-Solis et al. 1995). Southern blot was carried out to screen for NT-3 allele (NT-3-loxp allele) flanked by two loxp sites. ES clones with NT-3-loxp were injected into blastocysts for germ-line transfer. (d) Generation of $c k o^{-}$allele. Mice with NT-3-loxp allele were then crossed with Synapsin I-Cre (SynI-Cre) (Schoch et al. 1996) transgenic mice to produce NT-3 conditional knockout mice with cko allele. From a-d, restriction sites are (B) BamHI, (E) EcoRI. 
scribed in greater detail elsewhere (L. Ma, J. Marth, and L.F. Parada, in prep.) The design of the recombination cassette provided for the single NT-3 coding exon, as well as the TK-neo selection cassette, to be flanked by loxP sites (Fig. 1b). Removal of the TK-neo cassette was achieved by transient transfection of the homologous recombinant ES cells with a Cre-expressing vector pMC-Cre followed by a Southern blot screen of cell clones for selective deletion of the TK-neo cassette (Fig. 1c; data not shown; see below). cko ${ }^{+}$cell clones were blastocyst injected and subsequently introduced into the mouse germ line (data not shown). Mice homozygous for the $\mathrm{cko}^{+}$allele or compound heterozygotes for the $c k o^{+}$and the null allele (Tessarollo et al. 1994) have been maintained for more than four (>1.5 years) generations with no apparent physical or behavioral abnormalities (L. Ma, J. Marth, and L.F. Parada, in prep.).

NT-3 and its receptor trkC are widely expressed in the peripheral and central nervous systems in both neural and glial cells (Tessarollo et al. 1993). To examine the role of NT-3 expression exclusively in post-mitotic neurons, we crossed our NT-3 $\mathrm{cko}^{+}$mice to a transgenic line bearing a Synapsin I promoter-driven Cre transgene (Schoch et al. 1996). The SynI-cre mouse strain was crossed with $\mathrm{cko}^{+}$mice to generate $\mathrm{cko}^{-}$progeny (Fig. 1d). Figure 2a indicates that dramatic reduction of NT-3 $\mathrm{cko}^{+}$to $\mathrm{cko}^{-}$was observed in brain of mice of dual SynI-Cre, $\mathrm{cko}^{+/+}$genotype with minor cko appearance in other tissues (i.e., heart and kidney). This low level of cko- may reflect leakiness of the Syn-Cre transgene or, alternatively, minor contamination of the tissue preparations with sympathetic or parasympathetic neurons (Fig. 2a). Figure 2 a further demonstrates that no other mouse genotypes exhibited even traces of the $\mathrm{cko}^{-}$allele. Because the Synapsin I promoter has been characterized previously as neuron specific (Li et al. 1993; Schoch et al. 1996) and neurons consist of $\sim 20 \%$ of the cell population in the central nervous system, mice with a SynI-Cre/cko- genotype should have NT-3 ablated specifically in these cells. To examine this possibility, Southern blot hybridization was carried out to estimate the extent of $\mathrm{cko}^{+}$deletion in adult mouse brains ( 5 weeks). As shown in Figure $2 \mathrm{~b}, \mathrm{c}$, we estimate that as much as $60 \%$ of the $\mathrm{cko}^{+}$allele was transformed to $\mathrm{cko}^{-}$in the double transgenic mice. This result indicates that either the SynI-Cre transgenes expressed ectopically in non-neuronal cells or at low levels in progenitor cells, which may be common to neural and non- neural lineages. We further measured the expression of NT-3 mRNA in SynI-Cre/cko- mice by Northern blot hybridization of whole brain total RNA (Fig. 2d,e). In agreement with the genomic analysis, SynI-Cre/cko mice had low levels of NT-3 mRNA compared to $\mathrm{cko}^{+}$mice (Fig 2e). Finally, a reporter mouse strain designed to activate the $\beta$-galactosidase gene when Cre is expressed (Tsien et al. 1996) was crossed with SynI-Cre mice to analyze the expression pattern of Cre in the brain. As shown in Figure $2 \mathrm{f}$ and $\mathrm{g}, \operatorname{lac} Z$ reporter gene expression was observed in cortex, hippocampus, and diencephalon. Although neurons appear to be stained uniformly, it is also likely that some non-neural cells have also ablated the NT-3 gene in these mice.

SYNAPTIC TRANSMISSION AND PLASTICITY ARE NORMAL IN THE NT-3 CONDITIONAL KNOCKOUT MICE

To test the role of neuronal NT-3 in synaptic transmission and plasticity, we examined several indices of synaptic transmission in the conditional knockout (SynI-Cre/cko ${ }^{-}$) and control mice $\left(\mathrm{cko}^{+} / \mathrm{cko}^{+}\right)$at the Schaffer collateral-CA1 synapse in the hippocampus. Basal synaptic transmission in slices from the conditional knockout mice was indistinguishable from that in the control mice (Fig. 3). This was monitored by measuring the slope of the fEPSP (field EPSP) in response to electrical stimulation of varying current amplitudes. As shown in Figure 3, the mean responses obtained from conditional knockout slices were not significantly different from those obtained from control slices (N.S.).

In addition, two measures of short-term synaptic plasticity, paired-pulse facilitation (PPF) and post-tetanic potentiation (PTP), were also examined. PPF, observed at many different synapses, involves an augmentation of the synaptic response to the second of two closely spaced stimuli. It is likely mediated by residual intraterminal $\mathrm{Ca}^{2+}$ at the time of the second stimulus (e.g., Katz and Miledi 1968). The PPF observed in slices from the NT-3 knockout animals did not differ significantly from the controls at any of the interstimulus intervals (ISI) examined (Fig. 4) [PPF, mean percent of first response at $10 \mathrm{msec}$ ISI; knockout, $142.5 \pm 9.4 \%(n=5)$; control, $142.2 \pm 10.1 \%$ $(n=5) ; \quad(P=$ N.S. $) ; 25$ msec ISI: knockout, $144.9 \pm 4.7 \%(n=8$; control, $149.9 \pm 9.1 \%(n=8)$; $(P=$ N.S. $) ; 50$ msec ISI knockout, $151.7 \pm 4.2 \%$

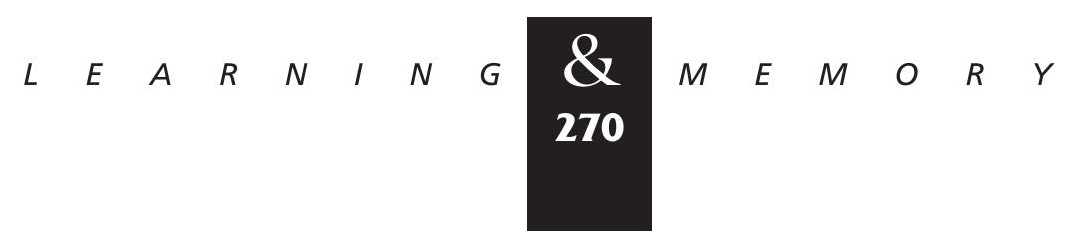


a

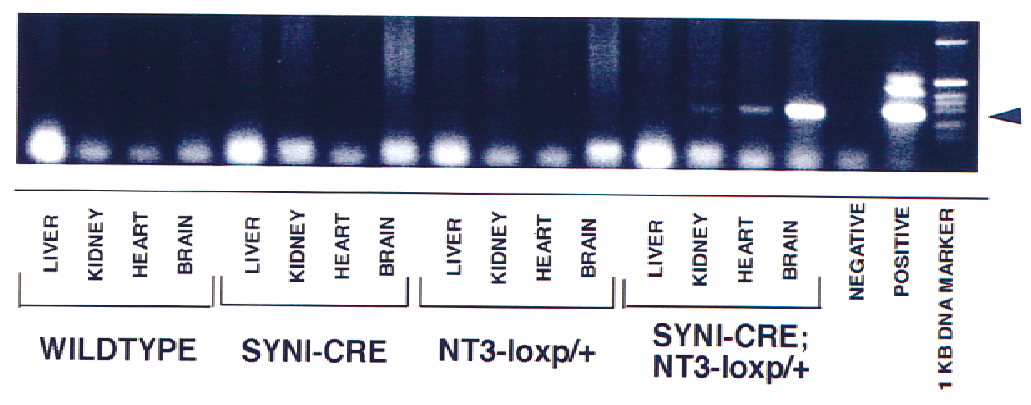

b

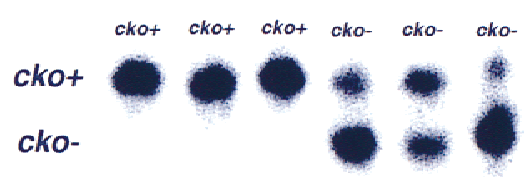

d
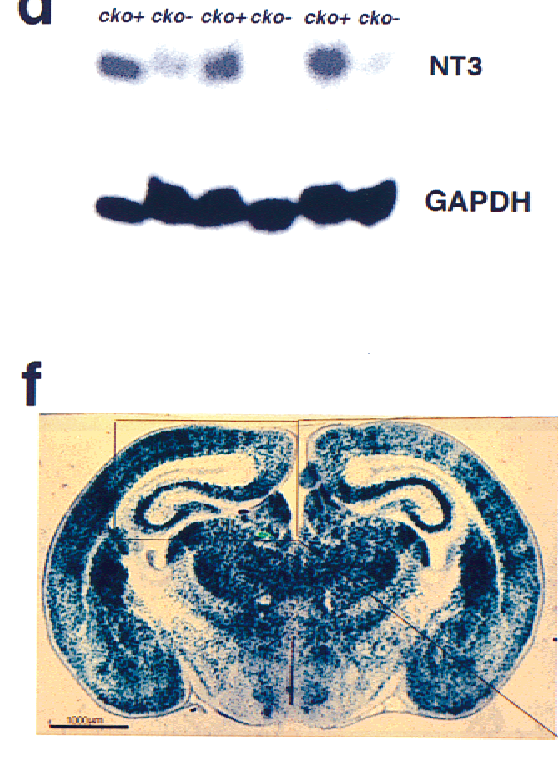

g

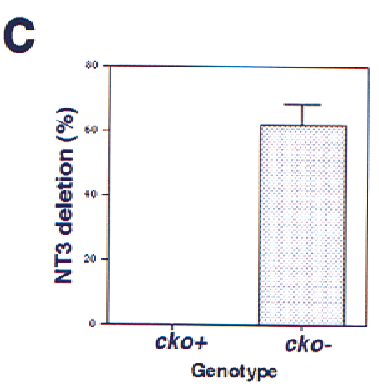

e
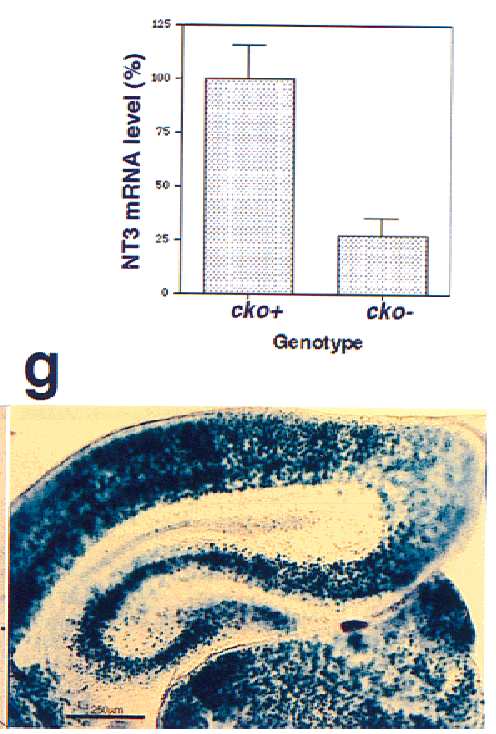

Figure 2: Characterization of Synl-Cre, NT-3 conditional knockout mice. (a) PCR assay from tissue genomic DNAs indicating the appearance in brain of Crespecific NT-3-loxp (cko-) allele (see arrowhead) indicating tissue specific cremediated looping out of the NT-3 coding exon. (b) Southern blot of whole brain genomic DNA to show the extent of the NT-3 deletion by Synl-Cre to transform the $c k o^{+}$allele into $c k o^{-}$. (c) Approximately $63 \%$ of the whole brain genomic $\mathrm{ckO}^{+}$allele was transformed into $\mathrm{cko}^{-}$ NT-3 gene by Synl-Cre. (d) Northern blot analysis of whole brain RNA with NT-3 probe to show the decrease of NT-3 mRNA after exposure to Synl-Cre. GAPDH mRNA was used as an internal loading control. (e) Quantification of NT-3 mRNA levels with Phosphorlmager indicates a $75 \%$ reduction brain NT-3 mRNA. $(f, g)$ Synl-Cre mice were crossed with a lac $Z$ reporter mouse strain (Tsien et al. 1996) to show the regions of Cre expression, which was recapitulated by lacZ expression. (g) Higher magnification of hippocampal region of $f$. $(f)$ Bar, $1000 \mu \mathrm{m}$; (g) bar, $250 \mu \mathrm{m}$. $(n=20)$; control, $142.6 \pm 2.5 \%(n=21 ; P=$ N.S. $)$; 100 msec ISI knockout, $141.7 \pm 2.4 \% \quad(n=20)$; control, $137.2 \pm 1.7 \%(n=21) ;(P=$ N.S. $)]$. In addition, analysis of the synaptic response immediately after $100 \mathrm{~Hz}$ or TBS (PTP) revealed no significant difference between slices from the knockout and control animals [mean percent of baseline after $100 \mathrm{~Hz}$ : knockout $255.2 \pm 15.3 \%(n=11)$; control $275.8 \pm 15.6 \%(n=10)(P=$ N.S. $)$; following theta burst: knockout, $211.1 \pm 18.1 \%(n=9)$; control,
$241.9 \pm 24.9 \%(n=11)(P=$ N.S. $)]$. We then addressed whether long-lasting plasticity was intact in slices from the neuronal NT-3 knockout mice. We found that two trains of $100 \mathrm{~Hz}$ stimulation (1 sec each) produced LTP in the knockout slices that was indistinguishable from that seen in the control slices (Fig. 5) mean percent of baseline 50-60 min after tetanus: knockout, $159.4 \pm 8.2 \% \quad(n=11)$; control, $169.1 \pm 7.3 \%(n=10)(P=$ N.S. $)]$. A recent study of the BDNF/TrkB dependence of LTP dem-

$$
\begin{array}{llllllllllllllll}
\hline & E & A & R & N & I & N & G & \mathbf{Q} & M & E & M & O & R & Y
\end{array}
$$




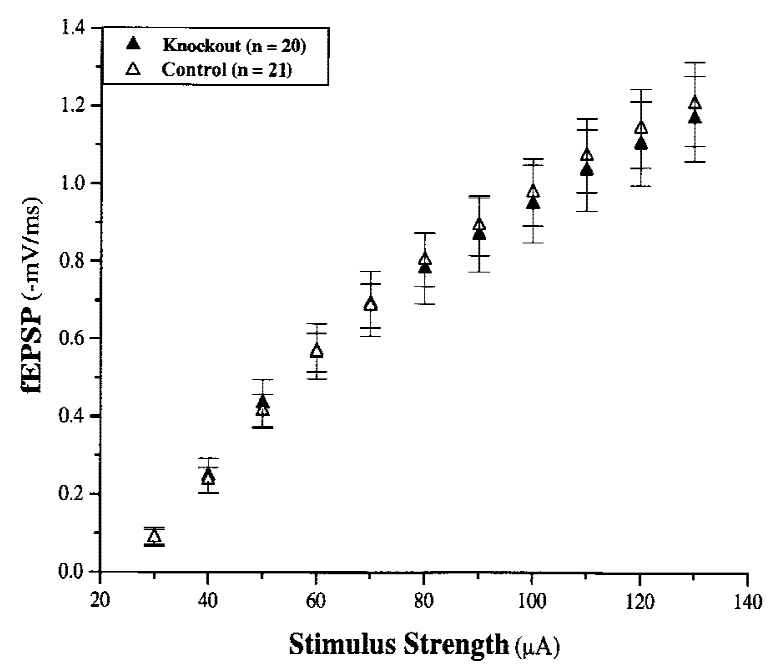

Figure 3: Input-output relations are normal in hippocampal slices from conditional neuronal NT-3 mutant mice. Shown are the mean fEPSP responses to stimuli of increasing strengths for both the knockout (Synl-cre/ $\left.c k \mathrm{O}^{-}\right)$and control $\left(c k \mathrm{O}^{+} / \mathrm{cko}^{+}\right)$slices. There was no significant difference between the two groups. (n) Number of slices. The number of animals from which the slices were taken was eight and eight, for the knockout and controls, respectively.

onstrated that the stimulation parameters used to induce LTP are an important determinant of whether TrkB is involved (Kang et al. 1997). LTP induced by $100 \mathrm{~Hz}$ stimulation was not blocked by function-blocking TrkB antibodies, whereas LTP induced by TBS was inhibited (Kang et al. 1997). As such, we also tested whether LTP induced by TBS (see Methods) was sensitive to neuronal NT-3 deletion. We found, however, that TBS-induced LTP was also normal in the NT-3 knockout slices [mean percent of baseline 50-60 min after TBS: knockout, $147.0 \pm 10.2 \% \quad(n=9) ; \quad$ control, $\quad 142.1 \pm 9.8 \%$ $(n=11)(P=$ N.S. $)]$. Taken together, these results indicate that neuronal NT-3 is not required for synaptic transmission or short- or long-term plasticity at the Schaffer collateral-CA1 synapse in the mouse hippocampus.

\section{Discussion}

Some of our SynI-Cre/cko- colony have surpassed a year of age with no apparent deleterious phenotypes (behavioral or pathological) resulting from ablation in most neurons and in a proportion of additional neural cells. We have also maintained NT-3 compound heterozygotes for the conditional and null alleles in the context of the Syn-Cre transgene. These mice have a complete somatic ablation of one NT-3 allele in addition to the ablation in all neurons and some glial cells of the second $\mathrm{cko}^{-}$ allele. We have yet to observe any overt pathological or behavioral phenotype in these mice (L. Ma and L. Parada, pers. comm.). Recently, Bates et al. (1999) reported the generation of a similar conditional NT-3 mutant mouse. Through use of a nestin promoter to drive Cre expression, NT-3 conditional deletion in the central nervous system and additional sites was reported. Unlike the Syn-Cre/ $c k o^{-}$described here, Bates and colleagues observed gait and behavioral abnormalities that they associated with cerebellar malfunction. We have not assessed directly the cerebellar morphology of our Syn-Cre/cko- mice to determine the extent of neural and non-neural ablation in this tissue.

The lack of effect of neuronal NT-3 deletion on synaptic transmission or plasticity differs from recent observations in $N T-3^{+/-}$mice, in which a decrease in paired-pulse facilitation was observed in the dentate gyrus (Kokaia et al. 1998). These NT- $3^{+/-}$mice show $\sim 30 \%$ reduction in NT-3 mRNA

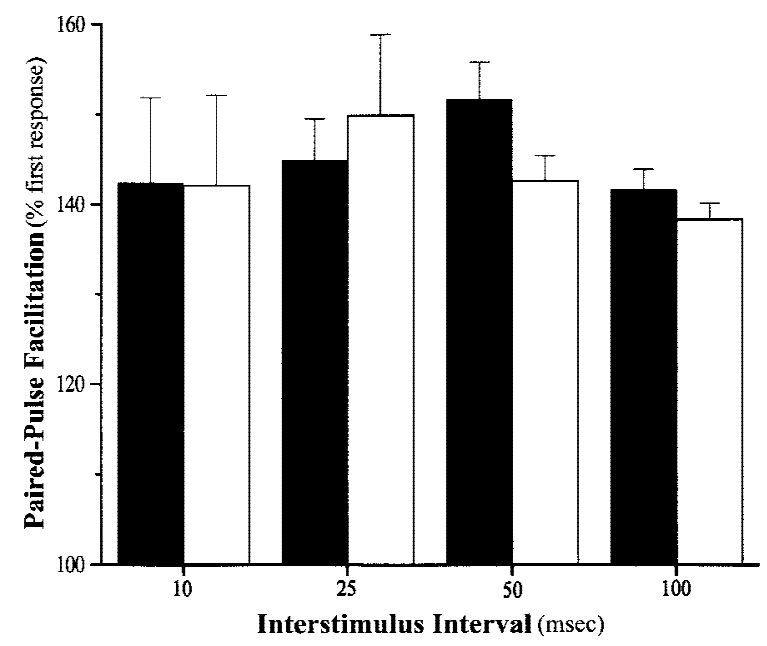

Figure 4: Paired-pulse facilitation is normal in hippocampal slices from conditional neuronal NT-3 mutant mice. Shown is the mean for three different interstimulus intervals. There was no significant difference between the knockout (solid bars) and control (open bars) slices at any of the intervals tested. The number of slices used for each interval is as follows (knockout/control): $10 \mathrm{msec}$ $(5,5) ; 25 \mathrm{msec}(8,8) ; 50 \mathrm{msec}(20,21) ; 100 \mathrm{msec}(20,21)$. The number of animals from which the slices were taken was 8 and 8 for the 50 and $100 \mathrm{msec}$ ISI, 3 and 3 for the $25 \mathrm{msec}$ ISI, and 2 and 2 for $10 \mathrm{msec}$ ISI for the knockout and controls, respectively.

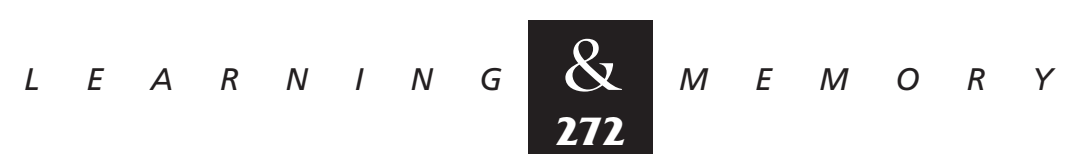


$\mathbf{a}$

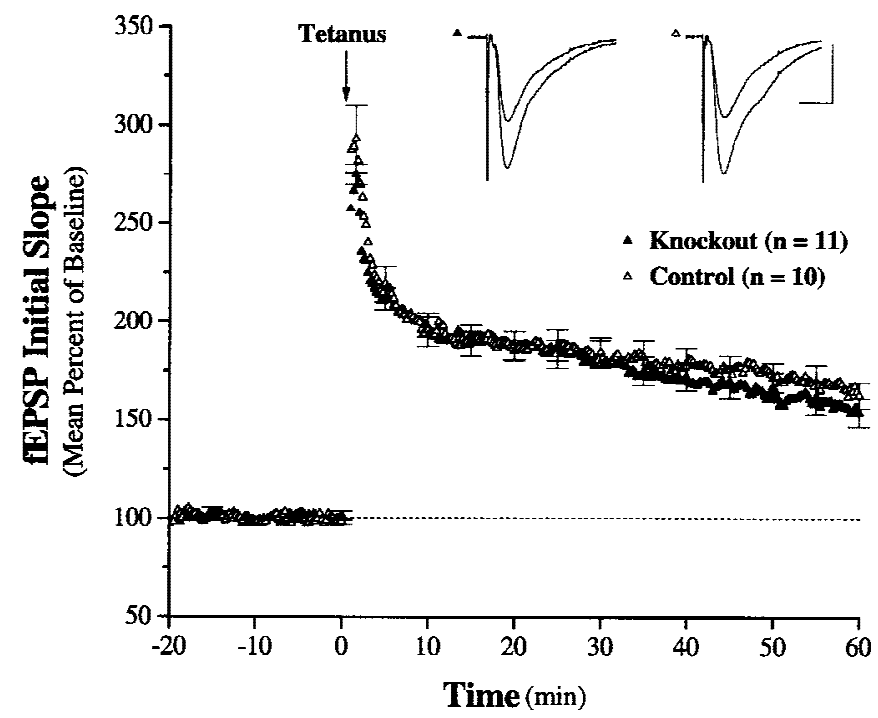

b

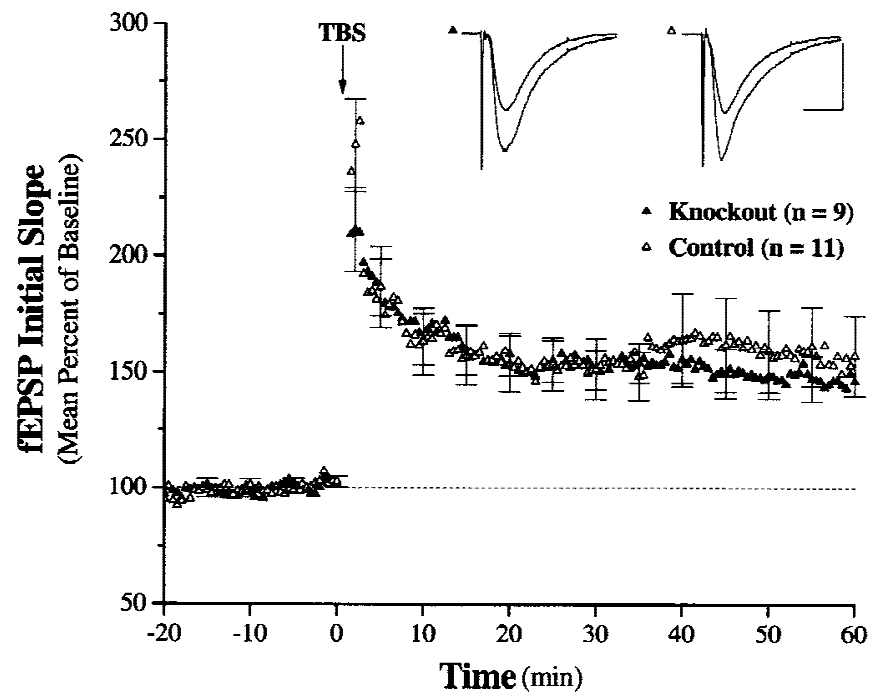

Figure 5: LTP is normal in hippocampal slices form conditional neuronal NT-3 mutant mice. (a) Ensemble averages for slices exposed to two epochs of $100 \mathrm{~Hz}$ stimulation (tetanus) for 1 sec each. Both the control and the mutant mice exhibited LTP, which was of a similar magnitude. In the mutant mice the mean fEPSP slope was $-0.25 \pm 0.02 \mathrm{mV} / \mathrm{msec}$ and $-0.38 \pm 0.02 \mathrm{mV} / \mathrm{msec}$, before and after LTP induction by $100 \mathrm{~Hz}$. These slices exhibited significant potentiation $(P<0.001)$. In the control mice the mean fEPSP slope was $-0.24 \pm 0.01 \mathrm{mV} / \mathrm{msec}$ and $-0.41 \pm 0.02 \mathrm{mV} /$ msec, before and after LTP induction by 100 $\mathrm{Hz}$. These slices also exhibited significant potentiation $(P<0.001)$. (n) Number of slices. The number of animals from which the slices were obtained was four and four for knockout and control mice, respectively. (b) Ensemble averages for slices exposed to TBS. Both the control and the mutant mice exhibited LTP, which was of a similar magnitude. In the mutant mice the mean fEPSP slope was $-0.25 \pm 0.02 \mathrm{mV} / \mathrm{msec}$ and $-0.36 \pm 0.03 \mathrm{mV} /$ msec, before and after LTP induction by TBS. These slices exhibited significant potentiation $(P<0.001)$. In the control mice the mean fEPSP slope was $-0.23 \pm 0.02 \mathrm{mV} / \mathrm{msec}$ and $-0.32 \pm 0.03 \mathrm{mV} / \mathrm{msec}$, before and after LTP induction by TBS. These slices also exhibited significant potentiation $(P<0.001)$. Bar, 0.5 $\mathrm{mV} / 100$ msec. (n) Number of slices. The number of animals from which the slices were obtained was four and four for knockout and control mice, respectively. levels in the dentate granule neurons (Elmer et al. 1997), but NT-3 levels in area CA1 have not been reported. Taken together these results suggest, however, that neuronal NT-3 plays different roles at Schaffer collateral-CA1 synapses versus dentate granule synapses. This is further substantiated by the observation that LTP induction results in upregulation of NT-3 in CA1 neurons (Patterson et al. 1992), but results in NT-3 down-regulation in dentate granule cells (Castren et al. 1993).

Our earlier studies demonstrated that application of either BDNF or NT-3 to hippocampal slices is sufficient to enhance synaptic transmission (Kang and Schuman 1995, 1996). To what extent does the neurotrophin-induced synaptic enhancement involve cellular mechanisms that overlap with LTP? Early experiments (Kang and Schuman 1995) examined the extent to which previous potentiation by either BDNF or NT-3 influenced the subsequent ability to obtain LTP at the same synapses. These experiments showed that LTP (induced by several trains of $100-\mathrm{Hz}$ stimulation) could still be elicited at synapses previously potentiated by neurotrophin. This implied that neurotrophin-induced potentiation and LTP used at least partially independent mechanisms. A later study (Kang et al. 1997) revealed, however, that the degree to which BDNF/TrkB-dependent potentiation

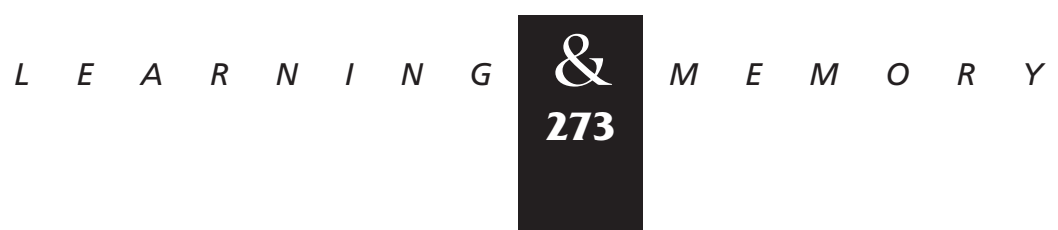


overlaps with LTP depends on the particular stimulation protocols used to induce LTP. That is, LTP induced by $100-\mathrm{Hz}$ stimulation was found to be independent of TrkB function, whereas LTP induced by more "subtle" stimulation protocols such as TBS or pairing required TrkB function (Kang et al. 1997). It was with this subtlety in mind that we tested both $100-\mathrm{Hz}$ and TBS-induced LTP in the NT-3 neuronal knockout. We found, however, that LTP was intact in both cases, indicating that neuronal NT-3 is not required for these forms of LTP.

Taken together with our earlier work (Kang and Schuman 1995), these data imply that NT-3 is sufficient, but not necessary, for synaptic potentiation in area CA1 of the hippocampus. One caveat concerns the species differences in these two sets of studies: NT-3-induced potentiation has been observed in rat hippocampus, but has not yet been reported in mouse hippocampus. An additional potentially noteworthy feature of our previous work with neurotrophins in hippocampal slices is the degree to which the potentiation elicited by either BDNF or NT-3 appeared to use similar cellular mechanisms. For example, both neurotrophins decreased PPF (Kang and Schuman 1995), required receptor tyrosine kinase activity (Kang and Schuman 1995a) and protein synthesis (Kang and Schuman 1996) for potentiation, and did not require NMDA receptor function for potentiation $(H$. Kang and E.M. Schuman, unpubl.). Although the synaptic enhancement elicited by BDNF is prevented completely by TrkB receptor blockade (Kang et al. 1997), preliminary experiments indicated that NT-3-induced potentiation is prevented only partially by blockade of TrkC function $(H$. Kang and E.M. Schuman, unpubl.). This raises the possibility that some of the potentiation produced by the application of exogenous NT-3 may be mediated by interactions with TrkB. If so, this could explain why the absence of neuronal NT-3 did not affect LTP in the present study, as other TrkB ligands, such as BDNF, could compensate.

The hippocampus is a prominent site of NT-3 expression (Ernfors et al. 1990). Our Northern blot analysis indicates that the conditional knockout resulted in $\sim 75 \%$ reduction of the NT-3 mRNA in brain. Moreover, the lac $Z$ expression pattern in the reporter mouse (Fig. 2f,g) indicates that the Cre recombinase was expressed robustly in the pyramidal cell layers of areas CA3 and CA1. These data, however, do not exclude the possibility that a nonneuronal source could provide the NT-3 required to sustain both synaptic transmission and plasticity at the Schaffer collateral-CA1 synapse. An analysis of mice in which NT-3 is deleted in glia will likely provide the answer to this question. In addition, given the abundance of neuronal NT-3 in the hippocampus, a more thorough analysis of the present conditional knockout mice may elucidate a previously unappreciated function for NT-3 in synaptic transmission.

\section{Acknowledgments}

We are grateful to Jamey Marsh for providing the syn-cre mouse, which will be described in detail elsewhere. L.F.P. and L.M. were supported by National Institutes of Health R01 NS33199. E.M.S. is a Pew Scholar and HHMI Assistant Investigator.

The publication costs of this article were defrayed in part by payment of page charges. This article must therefore be hereby marked "advertisement" in accordance with 18 USC section 1734 solely to indicate this fact.

\section{References}

Akaneya, Y., T. Tsumoto, S. Kinoshita, and H. Hatanaka. 1997. Brain-derived neurotrophic factor enhances long-term potentiation in rat visual cortex. J. Neurosci. 17: 6707-6716.

Bates, B., M. Rios, A. Trumpp, C. Chen, G. Fan, J.M. Bishop, and R. Jaenisch. 1999. Neurotrophin-3 is required for proper cerebellar development. Nat. Neurosci. 2: 115-117.

Castren, E., M. Pitkanen, J. Sirvio, A. Parsadanian, D. Lindholm, H. Thoenen, and P. Riekkinen. 1993. The induction of LTP increases BDNF and NGF mRNA but decreases NT-3 mRNA in the dentate gyrus. Neuroreport 4: 895-898.

Elmer, E., M. Kokaia, P. Ernfors, I. Ferencz, Z. Kokaia, and O. Lindvall. 1997. Suppressed kindling epileptogenesis and perturbed BDNF and TrkB gene regulation in NT-3 mutant mice Exp. Neurol. 145: 93-103.

Ernfors, P., C. Wetmore, and H. Persson. 1990. Identification of cells in rat brain and peripheral tissues expressing mRNA for members of the nerve growth factor family. Neuron 5: 511-526.

Ernfors, P., K.-F. Lee, J. Kucera, and R. Jaenisch. 1994. Lack of neurotrophin-3 leads to deficiencies in the peripheral nervous system and loss of limb proprioceptive afferents. Cell 77: 503-512.

Figurov, A., L.D. Pozzo-Miller, P. Olafsson, T. Wang, and B. Lu. 1996. Regulation of synaptic responses to high-frequency stimulation and LTP by neurotrophins in the hippocampus. Nature 381: 706-709.

Kang, H. and E.M. Schuman. 1995. Long-lasting neurotrophin-induced enhancement of synaptic transmission in the adult hippocampus. Science 267: 1658-1662.

1996. A requirement for local protein synthesis in

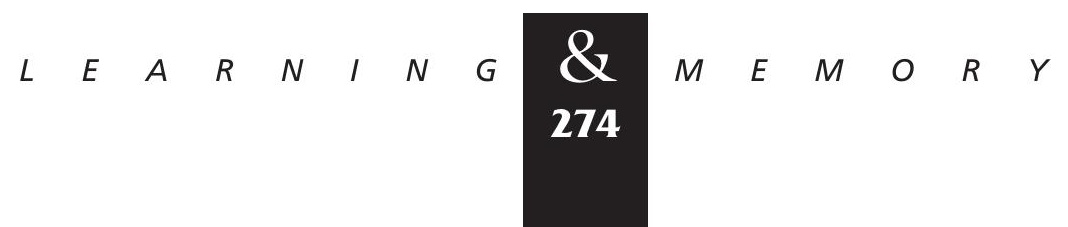


neurotrophin-induced synaptic plasticity. Science 273: 1402-1406.

Kang, H., D. Shelton, A. Welcher, and E.M. Schuman. 1997. Neurotrophins and time: Different roles for TrkB signaling in hippocampal long-term potentiation. Neuron 19: 653-664.

Katz, B. and R. Miledi. 1968. The role of calcium in neuromuscular facilitation. J. Physiol. 195: 481-492.

Kokaia, M., F. Asztely, K. Olofsdotter, C.B. Sindreu, D.M. Kullman, and O. Lindvall. 1998. Endogenous neurotrophin-3 regulates short-term plasticity at lateral perforant path-granule cell synapses. J. Neurosci. 18: 8730-8739.

Korte, M., P. Carroll, E. Wolf, E. Brem, H. Thoenen, and T. Bonhoeffer. 1995. Hippocampal long-term potentiation is impaired in mice lacking brain-derived neurotrophic factor. Proc. Natl. Acad. Sci. 92: 8856-8860.

Korte, M., O. Griesbeck, C. Gravel, P. Carroll, V. Staiger, H. Thoenen, and T. Bonhoeffer. 1996. Virus-mediated gene transfer into hippocampal CA1 region restores long-term potentiation in brain-derived neurotrophic factor mutant mice. Proc. Natl. Acad. Sci. 93: 12547-12552.

Kuhn, R., F. Schwenk, M. Aguet, and K. Rajewsky. 1995. Inducible gene targeting in mice. Science 269: 1427-1129.

Li, L., T. Suzuki, N. Mori, and P. Greengard. 1993. Identification of a functional silencer element involved in neuron-specific expression of the synapsin I gene. Proc. Natl. Acad. Sci. 90: 1460-1464.

Lohof, A.M., N. Ip, and M.-M. Poo. 1993. Potentiation of developing neuromuscular synapses by the neurotrophins NT-3 and BDNF. Nature 363: 350-353.

Patterson, S.L., L.M. Grover, P.A. Schwartzkroin, and M. Bothwell. 1992. Neurotrophin expression in rat hippocampal slices: A stimulus paradigm inducing LTP in CA1 evokes increases in BDNF and NT-3 mRNAs. Neuron 9: 1081-1088.

Patterson, S.L., T. Abel, T.A.S. Deuel, K.C. Martin, J.C. Rose, and E.R. Kandel. 1996. Recombinant BDNF rescues deficits in basal synaptic transmission and hippocampal LTP in BDNF knockout mice. Neuron 16: 1137-1145.

Ramirez-Solis, R., P. Liu, and A. Bradley. 1995. Chromosome engineering in mice. Nature 378: 720-724.

Sambrook, J., E.F. Fritsch, and T. Maniatis. 1989. Molecular cloning: A laboratory manual. Cold Spring Harbor Laboratory Press, Cold Spring Harbor, NY.

Schoch, S., G. Cibelli, and G. Thiel. 1996. Neuron-specific gene expression of synapsin I. Major role of a negative regulatory mechanism. J. Biol. Chem. 271: 3317-3323.

Schuman, E.M. 1999. Neurotrophin regulation of synaptic transmission. Curr. Opin. Neurobiol. 9: 105-109.

Tessarollo, L., P. Tsoulfas, D. Martin-Zanca, D.J. Gilbert,
N.A. Jenkins, N.G. Copeland, an L.F. Parada. 1993. trkC, a receptor for neurotrophin-3, is widely expressed in the developing nervous system and in non-neuronal tissues. Development 118: 463-475.

Tessarollo, L., K.S. Vogel, M.E. Palko, S.W Reid, and L.F. Parada. 1994. Targeted mutation in the neurotrophin-3 gene results in loss of muscle sensory neurons. Proc. Natl. Acad. Sci. 91: 11844-11848.

Tsien, J.Z., D.F. Chen, D. Gerber, C. Tom, E.H. Mercer, D.J. Anderson, M. Mayford, E.R. Kandel, and S. Tonegawa. 1996. Subregion and cell type-restricted gene knockout in mouse brain. Cell 87: 1317-1326.

Received June 7, 1999; accepted in revised form July 6, 1999.

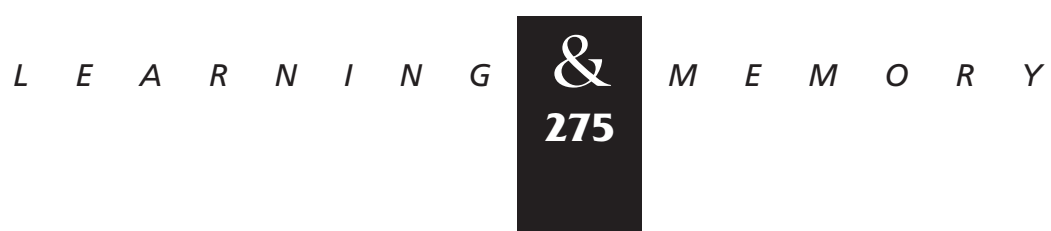




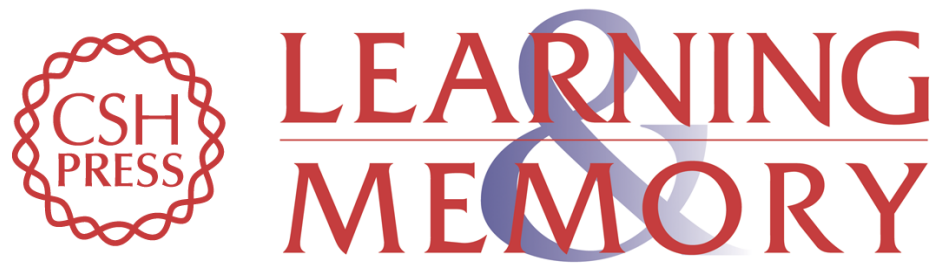

\section{Neuronal NT-3 Is not Required For Synaptic Transmission or Long-Term Potentiation in Area CA1 of the Adult Rat Hippocampus}

Long Ma, Gerald Reis, Luis F. Parada, et al.

Learn. Mem. 1999, 6:

Access the most recent version at doi:10.1101//m.6.3.267

References This article cites 24 articles, 11 of which can be accessed free at:

http://learnmem.cshlp.org/content/6/3/267.full.html\#ref-list-1

License

Email Alerting Receive free email alerts when new articles cite this article - sign up in the box at the Service top right corner of the article or click here. 